\title{
Characterization of Isolates of Ralstonia solancearum into Biovars based on their Ability to Oxidize and Utilize Disaccharides and Hexahydric Alcohols
}

\author{
C.R. Jahir Basha*, C.P. Manjula and M.K. Prasanna Kumar \\ Department of Plant Pathology, UAS, GKVK, Bangalore-65, India \\ *Corresponding author
}

\begin{tabular}{|c|c|}
\hline & A B S T R A C T \\
\hline $\begin{array}{l}\text { Ke y w o r d s } \\
\text { Ralstonia } \\
\text { solanacearum, } \\
\text { Biovars, } \\
\text { Karnataka. }\end{array}$ & \multirow{3}{*}{$\begin{array}{l}\text { The } 25 \text { isolates of Ralstonia solanacearum, a wilt causing bacterium } \\
\text { collected from different agro-climatic zones of Karnataka and other parts of } \\
\text { India tested for their ability of to oxidize and utilize disaccharides and } \\
\text { hexahydric alcohols tested in the present study revealed that, } 20 \text { isolates of } \\
R \text {. solanacearum isolated from tomato, potato, brinjal, bird of paradise, } \\
\text { capsicum and coleus belonged to biovar-III. The five isolates viz. KERT-I, } \\
\text { HRP, KERG-I, KERG- } 2 \text { and HRG isolated from tomato, potato and three } \\
\text { from ginger behaved differently and were unable to utilize dulcitol and } \\
\text { lactose and were categorized as biovar-IIIB. }\end{array}$} \\
\hline Article Info & \\
\hline $\begin{array}{l}\text { Accepted: } \\
\text { 19 June } 2017 \\
\text { Available Online: } \\
\text { 10 July } 2017\end{array}$ & \\
\hline
\end{tabular}

\section{Introduction}

Bacterial wilt of solanaceous vegetables and other crops caused by Ralstonia solanacearum (Smith) Yabuchi et al., (1995) is most lethal and highly destructive disease in the tropical and warm temperature regions of the world, causing heavy economic loss. The major economic hosts affected by this disease in India include tomato, potato, chilli, eggplant, ginger, groundnut, tobacco, banana and other floricultural plants. The disease affects solanaceous vegetables in most states of India (Kishun, 1980; Rao, 1976). In extreme cases loss in yield due to the disease in eggplant and tomato has been reported to be as high as 80 and 90 per cent, respectively (Rao, 1976). Representatives of 50 families comprising of more than 350 host plants are affected by this disease and that number of new species continue to increase (Hayward, 1991).

At present, biovar classification have gained wide acceptance for subdividing $R$. solanacearum. The biovar scheme divides the species into five groups on the ability of the strains to metabolise and / or oxidise specific hexose sugars and disaccharides (Hayward, 1964, 1991; He et al., 1983). This systems of classification proved as a useful means of cataloguing the diversity of the strains of Ralstonia solanacearum, it has provided little basis for understanding the origin and significance of their diversity. Keeping this in view, the present investigation was initiated to 
characterize the strains of $R$. solanacearum on the basis of oxidation and utilization of disaccharides and hexahydric alcohols.

\section{Materials and Methods}

The 25 isolates of $R$. solanacearum collected from different agro climatic zones of Karnataka and other parts of India (Table 1) were differentiated into biovars as per Hayward (1964) using carbohydrate fermentation discs supplied by $\mathrm{Hi}$ - mediaBombay.

Use of carbohydrate discs is reliable, simple and time saving as compared to conventional method such as inoculating the bacterial culture to sugar solution containing indicator bromothymol blue. Phenol red agar base medium (Himedia) a medium choused for $R$. solanacearum was prepared and autoclaved. The flasks were then cooled to $45^{\circ} \mathrm{C}$, then the bacterial suspension belonging to 25 isolates containing cell population of $5 \times 10^{5} \mathrm{cfu} / \mathrm{ml}$ were seeded separately with $0.8 \mathrm{OD}$ in spectrophotometer at $480 \mathrm{~nm}$. The flask was shaken to get uniform mixing of bacterial suspension. The seeded medium was poured to previously sterilized 4 inch Petri plate (20 $\mathrm{ml}$ ) and the medium was allowed to cool for 3 hours. Then the fermentation discs viz., cellobiose, lactose and maltose and sugar alcohols such as dulcitol, mannitol and sorbitol supplied by Himedia were placed in marked position in three locations in three Petri plates. Nine discs containing fermentation discs were maintained for each isolate.

The plates containing fermentation discs were incubated at $32^{\circ} \mathrm{C}$ for 48 hrs. The observations were recorded for change in color from light red to white and then to yellow with whitish creamy growth around the disc indicating the ability to utilize the sugars. Observations were recorded once at 18-24 hours and finally at the end of 48 hours.

\section{Results and Discussion}

The ability of the different isolates of Ralstonia solanacearum to oxidise and utilize disaccharides (cellobiose, lactose and maltose) and hexahydric alcohols (mannitol, dulcitol and sorbitol) was tested as per Hayward's classification (1964) and the data are presented in tables 2 and 3 .

Out of 25 isolates, 20 isolates of $R$. solanacearum isolated from tomato, brinjal, potato, capsicum and BOP obtained from different areas of Karnataka and other states of India oxidised and utilized all sugar alcohols viz., mannitol, dulcitol and sorbitol and disaccharides such as cellobiose, lactose and maltose as evidenced by the change in color of the bromothymol blue medium to yellow colour due to the production of acid in the medium. The three Kerala isolates viz., KERT-1, KERG-1 and KERG-2 and two from Karnataka i.e. HRG and HRP ginger and potato isolates, respectively from Hassan utilized the two disaccharides and two alcoholic sugars except one alcoholic sugar (Dulcitol) and one disaccharide (Lactose).

From the observation it is concluded that the 20 isolates of $R$. solanacearum from different agroclimatic regions of Karnataka and other parts of India belonged to biovar III. Shekhawat et al., (1978) recorded that strains causing brown rot of potato belonged to race-I and biovar- III and IV, further in 1992 they reported that pathogen isolated from plains belonged to race I and biovar-III, biovar IV was encountered only among the isolates from eastern parts of India. Race-III and biovar II were obtained only from few places in central plains and deccan plateu.

Venkatesh (2000) also reported the prevalence of biotype-III among the isolates infecting potato, tomato and ground nut. 
Table.1 Isolates of Ralstonia solanacearum collected from different agro-climatic zones of Karnataka and other states of India

\begin{tabular}{|l|l|l|l|}
\hline Sl.No. & Isolates & Host & Place \\
\hline 1 & HRT & Tomato & Hassan \\
\hline 2 & ORT-1 & Tomato & Orissa \\
\hline 3 & BRT & Tomato & Bangalore \\
\hline 4 & KERT-1 & Tomato & Kerala \\
\hline 5 & BRB & Brinjal & Bangalore \\
\hline 6 & BiRB & Brinjal & Bijapur \\
\hline 7 & KRB & Brinjal & Kolar \\
\hline 8 & KRP & Potato & Kolar \\
\hline 9 & HRP & Potato & Hassan \\
\hline 10 & SRP-1 & Potato & Simla \\
\hline 11 & SRP-2 & Potato & Simla \\
\hline 12 & KERG-1 & Ginger & Kerala \\
\hline 13 & KERG-2 & Ginger & Kerala \\
\hline 14 & HRG & Ginger & Hassan \\
\hline 15 & BRC & Chilli & Bangalore \\
\hline 16 & TuRC & Chilli & Tumkur \\
\hline 17 & TuRCa & Capsicum & Tumkur \\
\hline 18 & BOP-1 & Bird of paradise & Heserghatta, Bangalore \\
\hline 19 & BOP-2 & Bird of paradise & Heserghatta, Bangalore \\
\hline 20 & BRD-1 & Davana & Bangalore \\
\hline 21 & BRD-2 & Davana & Bangalore \\
\hline 22 & BRCo-1 & Coleus & Bangalore \\
\hline 23 & BRCo-2 & Coleus & Bangalore \\
\hline 24 & BRS-1 & Solanum & Bangalore \\
\hline 25 & BRGe & Geranium & Bangalore \\
\hline
\end{tabular}

Note: First alphabet codes for place, Second alphabet codes for pathogen (Ralstonia), third alphabet codes for host in the above isolates

Table.2 Characterization of isolates of Ralstonia solanacearum into biovars on the basis of utilization of disaccharides

\begin{tabular}{|r|l|c|c|c|}
\hline \multirow{2}{*}{ Sl.No. } & \multirow{2}{*}{ Isolate code } & \multicolumn{3}{|l|}{ Disaccharides } \\
\cline { 3 - 5 } & & Cellobiose & Maltose & Lactose \\
\hline 1 & HRT & + & + & + \\
\hline 2 & ORT-1 & + & + & + \\
\hline 3 & BRT & + & + & + \\
\hline 4 & KERT-1 & + & + & - \\
\hline 5 & BRB & + & + & + \\
\hline 6 & BiRB & + & + & + \\
\hline 7 & KRB & + & + & + \\
\hline 8 & KRP & + & + & + \\
\hline 9 & HRP & + & + & - \\
\hline 10 & SRP-1 & + & + & + \\
\hline 11 & SRP-2 & + & + & + \\
\hline
\end{tabular}




\begin{tabular}{|c|l|c|c|c|}
\hline 12 & KERG-1 & + & + & - \\
\hline 13 & KERG-2 & + & + & - \\
\hline 14 & HRG & + & + & - \\
\hline 15 & BRC & + & + & + \\
\hline 16 & TuRC & + & + & + \\
\hline 17 & TuRCa & + & + & + \\
\hline 18 & BOP-1 & + & + & + \\
\hline 19 & BOP-2 & + & + & + \\
\hline 20 & BRD-1 & + & + & + \\
\hline 21 & BRD-2 & + & + & + \\
\hline 22 & BRCo-1 & + & + & + \\
\hline 23 & BRCo-2 & + & + & + \\
\hline 24 & BRS-1 & + & + & + \\
\hline 25 & BRGe & + & + & + \\
\hline
\end{tabular}

+ Positive Reaction - Negative Reaction

Table.3 Characterization of isolates of Ralstonia solanacearum into biovars on the basis of utilization of Sugar alcohols

\begin{tabular}{|r|l|c|c|c|}
\hline \multirow{2}{*}{ Sl.No. } & \multirow{2}{*}{$\begin{array}{l}\text { Isolate } \\
\text { code }\end{array}$} & \multicolumn{3}{|c|}{ Sugar alcohols } \\
\cline { 3 - 5 } & HRT & + & + & + \\
\hline 2 & ORT-1 & + & + & + \\
\hline 3 & BRT & + & + & + \\
\hline 4 & KERT-1 & - & + & + \\
\hline 5 & BRB & + & + & + \\
\hline 6 & BiRB & + & + & + \\
\hline 7 & KRB & + & + & + \\
\hline 8 & KRP & + & + & + \\
\hline 9 & HRP & - & + & + \\
\hline 10 & SRP-1 & + & + & + \\
\hline 11 & SRP-2 & + & + & + \\
\hline 12 & KERG-1 & - & + & + \\
\hline 13 & KERG-2 & - & + & + \\
\hline 14 & HRG & - & + & + \\
\hline 15 & BRC & + & + & + \\
\hline 16 & TuRC & + & + & + \\
\hline 17 & TuRCa & + & + & + \\
\hline 18 & BOP-1 & + & + & + \\
\hline 19 & BOP-2 & + & + & + \\
\hline 20 & BRD-1 & + & + & + \\
\hline 21 & BRD-2 & + & + & + \\
\hline 22 & BRCo-1 & + & + & + \\
\hline 23 & BRCo-2 & + & + & + \\
\hline 24 & BRS-1 & + & + & + \\
\hline 25 & BRGe & + & + & + \\
\hline & & & & \\
\hline
\end{tabular}


Similarly Shobha (2002) classified 14 isolates collected from Karnataka and Orissa into biovar-III. Isolates of bird of paradise was identified to be biotype III (1999).

Bhattacharya et al., (2003) reported the prevalence of race-III and biotype-III infecting potato, tomato, aurbargine, chilly, jute and banana from West Bengal.

The five isolates viz. KERT-I, HRP, KERG-I, KERG-2 and HRG isolated from tomato, potato and three from ginger behaved differently and were unable to utilize dulcitol and lactose and are designated as biovar-IIIB, erected a new taxonomic group at the sub species level first of its kind within the biotype and designated as biovar-III $\mathrm{B}$ those isolates unable to utilizing the dulcitol and lactose (Prasanna, 2004).

Variation in ability of isolates to utilize sugars such as dulcitol were also reported and were designated their strains as biovar-IIIA (Mathew et al., 2002). Similarly, differences among the strains infecting potato in India and ability to utilize sugars and one strain could not utilize mannitol and maltose, which was designated as a typical strain (Sunaina et al., 1997).

\section{References}

Bhattacharya, P., Samajpatti, N. and Bhattacharya, P. 2003. Characteristics of Ralstonia (Pseudomonas) solanacearum from Gangetic West Bengal. J. Mycopath. Res., 41: 15-19.

Hayward, A.C. 1964. Characteristics of Pseudomonas solanacearum. J. Appl. Bacteriol., 27 : 265-271.

Hayward, A.C. 1991. Biology and Epidemiology of bacterial wilt caused by Pseudomonas solanacearum. Annu. Rev. Phytopathol., 29: 65-87.
He, L.Y., Sequiera, L. and Kelman, A. 1983. Characteristics of strains of Pseudomonas solanacearum from China. Plant Dis., 67: 1357-1361.

Kishun, R. 1980. Effect of antibiotics and fungicides on bacterial wilt of tomato. In: Proc. Fifth Inl. Conf. Pl. Pathogenic Bacteria, pp. 575-579.

Mathew, S.K., Girija, D., Binamol and James, B. 2002. Characterization of isolates of Ralstonia solanacearum causing bacterial wilt of ginger in Kerala. In: $3^{\text {rd }}$ Inter. Bacterial Sympo., p3.

Prasanna Kumar, M.K. 2004. Molecular characterization of the strains of $R$. solanacearum, (Yabuuchi), ecology and integrate management of bacterial wilt of tomato Ph.D Thesis, Univ. Agri. Sci., Bangalore. 235pp.

Rao, M.V.B. 1976. Bacterial wilt of tomato and eggplant in India. In: Proc. $1^{\text {st }}$ Planning Conf. and Workshop on Ecology and Control of Bacterial wilt caused by Pseudomonas solanacearum. (Eds.) L. Sequeira and A. Kelman, pp 92-94, North Carolina State Univ., Raleigh, 94 pp.

Shekhawat, G.S., Singh, R. and Kishore, V., 1978, Distribution of bacterial wilt and races and biotypes of the pathogen in India. J. Indian Potato Assoc., 5: 155165.

Shobha, G. 2002. Molecular, biochemical studies and pathogenecity test in the detection of races/strains of $R$. solanacearum causing wilt of solanaceous plants and their prevalence in Karnataka. Ph.D Thesis, Univ. Agri. Sci., Bangalore, 119pp.

Subhalaxmi, P.T. 1999. Studies on etiology, characterization ad control of the wilt of Bird of paradise (Sterilizia reginae). M.Sc. (Agri.) Thesis, Univ. Agric. Sci., Bangalore, $110 \mathrm{pp}$.

Sunaina, V., Kishore, V., Shekhawat, G.S. and Kumar, M., 1997. Control of 
bacterial wilt of potato in naturally infested soils by bacterial antagonists. J. Pl. Dis. Prot., 104: 362-369.

Venkatesh. 2000. Biology, Ecology and integrated management of bacterial wilt of potato caused by Ralstonia solanacearum. Ph.D Thesis, Univ. Agri. Sci., Bangalore, 129pp.

Yabuuchi, E., Kosako., Yano, I., Hotta, H. and Nishiuchi, Y. 1995. Transfer of two
Burkholderia and an Alcaligenes species to Ralstonia Gen. Nov. Proposal of Ralstonia pickettii (Ralston, Palleroni and Doudoroff 1973) Comb. Nov. Ralstonia solanacearum (Smith 1896) Comb. Nov. and Ralstonia eutropha (Davis 1969) Comb. Nov., Microbiol. Immunol., 39: 897-904.

\section{How to cite this article:}

Jahir Basha, C.R., C.P. Manjula and Prasanna Kumar, M.K. 2017. Characterization of Isolates of Ralstonia solancearum into Biovars based on their Ability to Oxidize and Utilize Disaccharides and Hexahydric Alcohols. Int.J.Curr.Microbiol.App.Sci. 6(7): 1754-1759. doi: https://doi.org/10.20546/ijcmas.2017.607.211 